\title{
Effect of noxythiolin on experimental peritonitis
}

\author{
O. J. A. Gilmore \\ M.S., F.R.C.S., F.R.C.S. (Ed.) \\ Elizabeth T. HouANG \\ M.B.B.S., M.R.C.Path. \\ Clare Reid \\ Elizabeth J. Shaw \\ B.Sc., A.I.M.L.S. \\ M.D., B.S., F.R.C.Path. (Aust)

\begin{abstract}
Surgical Professorial Unit and Department of Medical Microbiology, St Bartholomew's Hospital, London ECI
\end{abstract}

\begin{abstract}
Summary
The intraperitoneal instillation of noxythiolin in the treatment of peritonitis is widespread in clinical practice despite contradictory evidence as to its efficacy. In this light the value of noxythiolin was reappraised by studying its effect in guinea-pigs and mice with induced bacterial peritonitis. Treatment with a $1 \%$ solution of noxythiolin reduced the mortality rate of mice by $14 \%(P<0 \cdot 1)$. The guinea-pig model proved unreliable giving inconsistent mortality rates throughout. Further studies are required to determine the optimum dose and concentration of noxythiolin while the search for more effective intraperitoneal antiseptics should continue.
\end{abstract}

\section{Introduction}

Intraperitoneal noxythiolin (Noxyflex) is lethal. This was the conclusion reached by King, Gurry and Brooke (1975a) when they studied rabbits with peritonitis from perforated appendicitis. Tolhurst Cleaver et al. (1974) concluded that noxythiolin was no more effective than Hartmann's solution in reducing the mortality of rats with peritonitis.

Despite these animal studies intraperitoneal noxythiolin is often used in clinical practice. Its popularity stems from the work of Stoller (1967) and Browne and Stoller (1970) who showed that noxythiolin significantly reduced the mortality rate of guinea-pigs with bacterial peritonitis. They also reported an impressive series of twenty-three patients with faecal peritonitis: there were only three deaths and two of these were due to pulmonary emboli.

The antimicrobial action of noxythiolin $(N$ hydroxy-methyl' $N$ '-methylthiourea) is not fully understood, but various explanations have been forwarded. Pichard (1972) attributed its bactericidal action to the liberation of formaldehyde. Chemically, noxythiolin is similar to methyl mustard oil which has a wide antibacterial spectrum, another possible explanation for its activity (King et al., 1975a). A recent study showed that it significantly reduces peritoneal adhesion formation (Gilmore and Reid, 1976) while other studies show noxythiolin to have anti-endotoxin (Wright and McAllister, 1967) and anti-mitotic properties (Jamieson, 1972; Desai and Jamieson, 1973). It has been suggested that the bactericidal and anti-adhesive actions of noxythiolin may be non-specific owing to interference with cell division (Gilmore, 1976).

Because the intraperitoneal use of noxythiolin in peritonitis is common and the evidence of its efficacy is contradictory the authors considered a reassessment of its value to be important.

\section{Guinea-pig studies}

Using female Dunkin-Hartley guinea-pigs, it was attempted to establish a model for both coliform (Escherichia coli 0111B4) and mixed bacterial (E. coli 0111B4 and Bacteroides fragilis NC9363) peritonitis. However, mortality rates were very inconsistent so it was decided to investigate the possibilities of a mouse model.

\section{Mouse studies}

Female, Theiller Original, specific pathogen-free mice weighing 20-25 g were used exclusively. In 1973 Rogers showed that $E$. coli $0141 / \mathrm{K} 85 / \mathrm{H} 4$ would multiply in the peritoneal cavity of this mouse. Consequently these same strains were used in the following experiments for the induction of experimental peritonitis.

Study 1 : Establishing a model for bacterial peritonitis

Four groups of mice were injected intraperitoneally with $E$. coli, as shown in Table 1 . The incidence and time of death of each mouse was recorded.

All mice dying from peritonitis did so within 4-18 hours. The mortality rate increased with the bacterial content rather than the volume of the inoculum. At post-mortem the only abnormality seen was a hyperaemic peritoneum. A bacterial 
TABLE 1. Mortality of mice with untreated bacterial peritonitis

\begin{tabular}{lccccc}
\hline & \multicolumn{2}{c}{ Escherichia coli inoculum } & & \multicolumn{2}{c}{ No. of mice } \\
\cline { 2 - 3 } \cline { 5 - 6 } Group & $\begin{array}{c}\text { Volume } \\
(\mathrm{ml})\end{array}$ & $\begin{array}{c}\text { No. of } \\
\text { organisms }\end{array}$ & & Total & Deaths \\
\hline A & 0.2 & $4 \times 10^{5}$ & 10 & 0 \\
B & 0.4 & $8 \times 10^{5}$ & 10 & 2 \\
C & 0.2 & $4 \times 10^{6}$ & 10 & 4 \\
D & 0.2 & $2 \times 10^{7}$ & 10 & 6 \\
\hline
\end{tabular}

swab taken from the peritoneal cavity grew a pure culture of $E$. coli in every case. Surviving animals were killed at 1 week and examined. No abnormalities were seen, and again the bacterial swab always grew a pure culture of $E$. coli.

It was concluded from this study that the injection of $E$. coli, $10^{7}$ organisms $/ \mathrm{ml}$ would give a mortality rate of $50-60 \%$.

\section{Study 2: Intraperitoneal noxythiolin in peritonitis Preliminary study}

Materials and methods. Eighty mice were injected with $0.2 \mathrm{ml} \mathrm{E}$. coli, $10^{7}$ organisms $/ \mathrm{ml}$. One minute later the mice were injected accordingly:

Group A: Control: nothing.

Group B: Control: $0.2 \mathrm{ml}$ Ringer's solution.

Group C: $0.2 \mathrm{ml}$ noxythiolin, $1 \%$ solution.

Group D: $0.2 \mathrm{ml}$ noxythiolin, $0.5 \%$ solution.

The mortality rate in each group was recorded and all survivors were killed at 1 week. A post-mortem examination was performed on every animal shortly after death and a bacterial swab was taken from the peritoneal cavity.

Results. As in the previous study, all mice dying from peritonitis perished within 4-18 hours of its induction. The mortality rates are given in Table 2 . The survival rate of mice treated with noxythiolin $1 \%$ was greater than that of those receiving noxythiolin $0.5 \%$, but this difference was not significant. The mortality rate was identical in the two control groups. The post-mortem findings were identical to those of the previous study.

\section{Definitive study}

Materials and methods. This study comprised eight similar experiments in which 220 mice were injected intraperitoneally with $E$. coli, $10^{7}$ organisms/

TABLE 2. Effect of intraperitoneal noxythiolin in mice with bacterial peritonitis-preliminary study

\begin{tabular}{lcc}
\hline Treatment group & Total & Deaths \\
\hline A. Control: nothing & 20 & 12 \\
B. Control: 0.2 ml Ringer solution & 20 & 12 \\
C. $0.2 \mathrm{ml}$ noxythiolin $1.0 \%$ solution & 20 & 11 \\
D. $0.2 \mathrm{ml}$ noxythiolin $0.5 \%$ solution & 20 & 13 \\
\hline
\end{tabular}

$\mathrm{ml}$. One minute later each mouse received a seconf injection by random allocation:

Group A: Control: $0.2 \mathrm{ml}$ Ringer's solution.

Group B: $0.2 \mathrm{ml}$ noxythiolin $1 \%$.

The mortality rate in each group was recorded an all survivors were killed at 1 week.

Results. The results of this study are given i Table 3. The mortality rate of the control group was

TABLE 3. Effect of intraperitoneal noxythiolin in mice witff bacterial peritonitis-definitive study

\begin{tabular}{|c|c|c|c|}
\hline Treatment group & Total & Deaths & Significance- \\
\hline $\begin{array}{l}\text { A. Control: } 0.2 \mathrm{ml} \text { Ringer } \\
\text { solution }\end{array}$ & 110 & 72 & 2 \\
\hline $\begin{array}{l}\text { B. } 0.2 \text { ml noxythiolin } 1 \% \\
\text { solution }\end{array}$ & 110 & 57 & $P<0.1$ \\
\hline
\end{tabular}

$65.5 \%$ and that of the treated group $51.8 \%$. The reduced mortality rate of mice treated with noxy= thiolin $1 \%$ compared with the control group is significant at the $10 \%$ level $\left(\chi^{2}=3 \cdot 67, P<0 \cdot 1\right)$. Again as in the previous two studies, all mice dying from peritonitis perished within 4-18 hours, and at postmortem the only abnormality found was a hypere aemic peritoneum.

\section{Discussion}

Theiller Original mice injected with $E$. coli 0141 $10^{7}$ organisms $/ \mathrm{ml}$ give a reliable, reproducible an inexpensive model for the study of peritonitis. The majority of mice dying of peritonitis perished within 4-8 hours of its induction, and all died withiQ $18 \mathrm{hr}$. This indicates the rapidly progressive nature of the peritonitis induced.

Intraperitoneal noxythiolin $1 \%$ in the dose range $80-100 \mathrm{mg} / \mathrm{kg}$ body-weight reduced the mortality of mice with peritonitis by $14 \%$ (Table 2 ), but thes:reduction was not quite significant. Tolhurst Cleave et al. (1974) found Hartmann's solution superior t8 noxythiolin $0.5 \%$ and $0.125 \%$ in the treatment of ra专 faecal peritonitis: in this preliminary mouse studळ $0.5 \%$ noxythiolin was found to be ineffective. Kin et al. $(1975 \mathrm{a}, \mathrm{b})$ have published papers on peritonitis in rabbits due to perforation of the appendix. The found that significantly more rabbits died which were receiving $5 \mathrm{ml}$ of $2.5 \%$ or $10 \%$ noxythiolin solutions than those receiving normal saline. Brownes and Stoller (1970), on the other hand, found that noxythiolin $(500 \mathrm{mg} / \mathrm{kg}$ body-weight) significant reduced the mortality of guinea-pigs with bacteriaf peritonitis $(P<0.001)$.

There are a number of possible explanations for these varying results. Different animals were studiec6 different methods of inducing peritonitis were used 
the treatment-free interval varied, as did the concentration and dose of noxythiolin given. It may well be that the effectiveness of noxythiolin in peritonitis is not only dose-specific, but also species-specific.

King et al. (1975a, b) have described an animal model which simulates perforation of the appendix. Unfortunately any model which mimics the clinical situation produces an uncontrolled peritonitis: furthermore, laparotomy introduces another variable owing to the inevitable loss of intraperitoneal fluid. The only satisfactory method of producing a controlled peritonitis for experimental studies is to inject a known amount of bacteria or a standard suspension of faeces.

In clinical peritonitis all the evidence for the efficacy of noxythiolin comes from uncontrolled studies (Browne and Stoller, 1970; Pickard, 1972; Leger, Moulle and de Laitre, 1972). In a controlled trial, Gurrey et al. (1976) found $100 \mathrm{ml}$ of noxythiolin $2.5 \%$ to be no more effective than $100 \mathrm{ml}$ of normal saline in preventing complications in perforated appendicitis. No adverse reports of noxythiolin in clinical practice have however been published, nor did Gurry et al. (1976) notice any in their trial.

A number of conclusions may be drawn from the present studies. Dunkin-Hartley guinea-pigs offer unreliable models for the study of peritonitis. Theiller Original mice injected with $E$. coli 0141 provide a reliable and inexpensive model for peritonitis studies. Intraperitonitoneal noxythiolin $0.5 \%$ solution is ineffective, while a $1 \%$ solution ( $80-100$ $\mathrm{mg} / \mathrm{kg}$ body-weight) reduces the mortality of mice $(P<\mathbf{0} \cdot 1)$ when given 1 minute after the induction of peritonitis. Intraperitoneal noxythiolin at these concentrations is therefore not lethal, but further studies are required to determine its optimum concentration and dosage, while the search for more effective intraperitoneal antiseptics should continue.

\section{Acknowledgments}

We are indebted to Professor G. W. Taylor for his encouragement and advice throughout this study. Our thanks are due to $\mathrm{Mr}$ John $\mathrm{A}$. Lewis and Miss Elaine Laws for statistical advice and Miss Janice Blackford for preparing the typescript. Noxyflex is a product of Geistlich Sons Ltd who provided the noxythiolin used in this study. O. J. A. Gilmore gratefully acknowledges the Joint Research Board of St Bartholomew's Hospital for the Aylwen Bursary of which he was in receipt during this study.

\section{References}

BROWNE, M.K. \& STOLLER, J.L. (1970) Intraperitoneal noxytiolin in faecal peritonitis. British Journal of Surgery, $57,525$.

DesaI, S. \& JAmieson, C.W. (1973) Intraperitoneal noxytiolin as an experimental chemotherapeutic agent. British Journal of Surgery, 60, 350.

Gilmore, O.J.A. (1976) A reappraisal of the use of antiseptics in general surgery. M.S. Thesis University of London.

Gilmore, O. J. A. \& Reid, C. (1976) Noxytiolin and peritoneal adhesions. British Journal of Surgery, 63, 978.

GurRy, J.F., KInG, D.W., RuTTER, K.P. \& Brooke, B.N. (1976) A controlled trial of noxytiolin in perforated appendicitis. British Journal of Surgery, 62, 401.

JAMIESON, C.W. (1972) Inhibition of the growth of tumour cells in culture by noxytiolin. British Journal of Surgery, $59,108$.

King, D.W., Gurry, J.F. \& Brooke, B.N. (1975a) The effect of noxytiolin in experimental peritonitis. British Journal of Surgery, 62, 645.

King, D.W., Gurry, J.F., Ellis-Pegler, R.B. \& Brooke, B.N. (1975b) A rabbit model of perforated appendicitis with peritonitis. British Journal of Surgery, 62, 642.

Leger, L., Moulle, P. \& De Laitre, B. (1972) Noxythioline intra-péritonéale dans les péritonites généralisées. Chirurgie 98, 539.

Pickard, R.G. (1972) Treatment of peritonitis with preand post-operative irrigation of the peritoneal cavity with noxythiolin solution. British Journal of Surgery, 59, 642.

ROGERS, H.J. (1973) Iron-binding catechols and virulence in Escherichia coli. Infection and Immunity, 7, 445.

Stoller, J.L. (1967) Faecal peritonitis. Clinical Trials Journal, 4, 670.

Tolhurst Cleaver, C.L., Hopkins, A.D., Kee Kwong, K.C.N.G. \& RAFTERY, A.T. (1974) The effect of postoperative peritoneal lavage on survival, peritoneal wound healing and adhesion formation following faecal peritonitis; an experimental study in the rat. British Journal of Surgery, 61, 601.

Wright, C.J. \& MCAllister, T.A. (1967) Protective action of noxytiolin in experimental endotoxaemia. Clinical Trials Journal, 4, 680. 